\title{
Rates of changes in organic matter and nutrient stocks during seagrass Cymodocea nodosa colonization and stand development
}

\author{
Morten F. Pedersen ${ }^{1, *}$, Carlos M. Duarte ${ }^{2}$, Just Cebrián ${ }^{3}$ \\ ${ }^{1}$ Department of Life Sciences and Chemistry 17.2, University of Roskilde, Box 260, DK-4000 Roskilde, Denmark \\ ${ }^{2}$ Centre d'Estudis Avançats de Blanes, C.S.I.C., Cámi de Santa Bárbara s/n, E-17300 Blanes, Girona, Spain \\ ${ }^{3}$ Boston University Marine Program (Marine Biological Laboratory), Woods Hole, Massachusetts 02543, USA
}

\begin{abstract}
The rates of changes in stocks of organic matter and major nutrients ( $N$ and $P$ ) during colonization and development of seagrass Cymodocea nodosa biomass in a semi-closed estuary, Alfacs Bay, Spain, were studied. The non-vegetated sediments of Alfacs Bay contain large reserves of $N$ and $P$, but most of these nutrients are not readily available for plant growth as they are tied up in organic matter or mineral fractions within the sediment. Seagrass biomass per unit area increased linearly during the first 5 yr after colonization although the very low tissue concentrations of $P$ in leaves of $C$. nodosa suggested $P$ limitation. Development of plant biomass was accompanied by a net accumulation of $\mathrm{N}$ at a rate of $3.6 \mathrm{~g} \mathrm{~N} \mathrm{~m}^{-2} \mathrm{yr}^{-1}$ Half of this increase was caused by the build up of plant-bound $\mathrm{N}$ in living and dead biomass, while the other half was accounted for by accumulation in other $N$ fractions. $P$ accumulated as plant-bound $P$, but this fraction constituted less than $1 \%$ of the total $P$ pool. Accumulation of plant-bound $\mathrm{P}$ was of the same magnitude as depletion of other $\mathrm{P}$ fractions, leaving the pool of total P unaffected by plant development. These results suggest that colonization and development $C$. nodosa in Alfacs Bay facilitate capture and accumulation of external $\mathrm{N}$ within the stands, while $\mathrm{P}$ may be mobilized from mineral-bound $\mathrm{P}$ reserves within the sediments.
\end{abstract}

KEY WORDS: Nutrient accumulation · Phosphorus · Nitrogen - Seagrasses - Sediments - Estuaries

\section{INTRODUCTION}

Colonization and early development of terrestrial vegetation on bare soils are often associated with accumulation of organic matter (OM) and major nutrients due to increased import and reduced export of nutrients (Vitousek \& Reiners 1975, Tilman 1985, 1988). The development of seagrass stands is believed to involve changes in nutrient and organic stocks associated with the successional sequence. Existing evidence shows that seagrasses can have a profound influence on local biogeochemical processes (Kenworthy et al. 1982, Williams 1990, Romero et al. 1992) leaving seagrass communities amongst the ecosystems with the greatest influence on nutrient cycling (Costanza et al. 1997). Yet, the quantitative knowledge of the changes in

•E-mail.mfp@virgil.ruc.dk nutrient stocks during seagrass colonization is still meager, and thus these changes are not able to be forecasted. There is, therefore, a need to evaluate the rates at which these changes take place, as well as to test whether rates for different nutrient elements are correlated.

Changes in nutrient stocks associated with the development of seagrass communities imply a change in the processes of nutrient gains and losses mediated by the plants. Nutrient inputs result from sedimentation of particulate matter, uptake of inorganic nutrients from the water and from $\mathrm{N}$ fixation, whereas output of nutrients is due to exudation of dissolved nutrients from plant material, export of plant material, export by foraging animals, and denitrification (reviewed by Hemminga et al. 1991). The balance determines whether nutrients accumulate or become depleted within seagrass systems during the course of vegeta- 


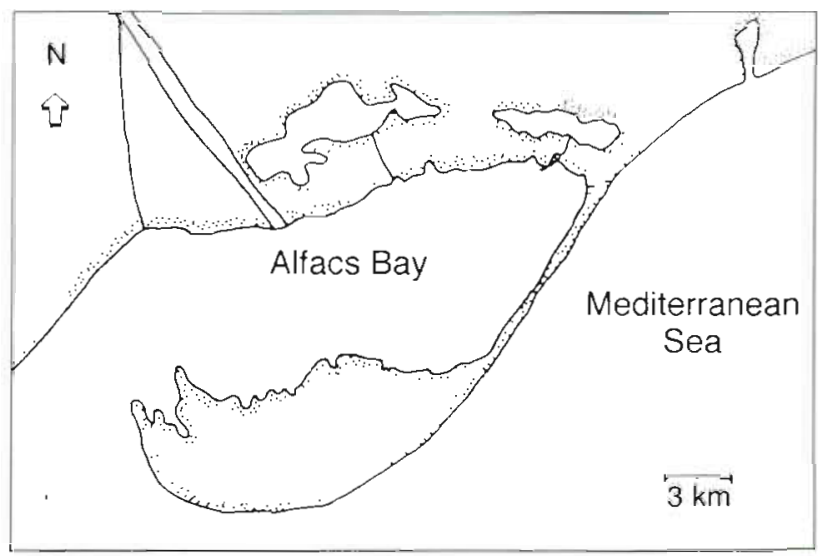

Fig. 1. Study site, Alfacs Bay, in the Ebro Delta, NW Mediterranean, Spain

tion development, but most studies on nutrient stocks in seagrass beds suggest that accumulation of $O M$ and major nutrients is a common feature (e.g. Kenworthy et al. 1982, Williams 1990, Romero et al. 1992).

Although most studies focus on $\mathrm{N}$, seagrasses can also have significant effects on the biogeochemistry of P (e.g. Patriquin 1972, Morse et al. 1987, Jensen et al. 1997), particulary since $P$ limitation is common in many seagrass ecosystems (e.g. Short et al. 1985, 1990, Short 1987, Perez et al. 1991). While most of the $N$ present in ecosystems is largely associated with organic components, most $\mathrm{P}$ is found in mineral components, from which it can be made available by weathering processes or dissolution and subsequent uptake by plants (Tiessen \& Stewart 1985, Hoffland et al. 1989). Hence, it has been hypothesized that stocks of total P within terrestrial ecosystems become depleted during plant colonization and development, because hardly available $\mathrm{P}$ (mostly $\mathrm{Ca}$-bound $\mathrm{P}$ ) is slowly mobilized under the influence of plants, and finally lost from the system through litter export or wash-out (Walker \& Syers 1976, Crew et al. 1995). It is possible, therefore, that the development of seagrass biomass may cause the accumulation of some nutrients yet the depletion of others.

Here we examine how colonization and subsequent biomass development of the seagrass Cymodocea nodosa affect the accumulation or depletion of $O M$ and major nutrients ( $N$ and $P$ ) in the sediments. Also, we estimate the rates of accumulation and depletion of these stocks. We do so by quantifying various fractions of OM and major nutrients and comparing them along a gradient of increasing seagrass biomass and time since colonization. C. nodosa is well suited for these kinds of studies, because individual plants can be aged and the time since colonization can be established (Duarte et al. 1994), which allows the approximate rate of pool changes to be estimated.

\section{MATERIALS AND METHODS}

Sampling procedures. The study was carried out during July 1994 in Alfacs Bay (40³6' N, $0^{\circ} 43^{\prime}$ E; NW Mediterranean), a shallow estuarine bay in the Ebro Delta (Fig. 1) where Cymodocea nodosa is the dominant seagrass. Transects were placed across the longest axis of 12 clearly defined patches, from $5 \mathrm{~m}$ outside each patch to the centre. Biomass and sediment samples were obtained along each transect at several positions: $5 \mathrm{~m}$ outside, at the edge, and in the centre of the patch. A variable number of samples (1 to 7 depending on patch size) were also taken between the edge and the centre of each patch.

Biomass samples were taken with a core-sampler $\left(0.0314 \mathrm{~m}^{2}\right)$ inserted $10 \mathrm{~cm}$ into the sediments. Plant biomass was sorted into alive above-ground material, alive below-ground material and dead below-ground material. All shoots in each sample were aged according to Duarte et al. (1994), and the oldest shoot was used to determine the minimum time elapsed since colonization. The time unit is plastochrone intervals (PI), which was translated into absolute time by multiplying with the average time elapsed between the production of successive leaves for the population studied (Marbà \& Duarte 1995). All biomass samples were finally dried, weighed and stored for analysis of OM, nitrogen, and phosphorus. Triplicate sediment samples (depth $=10 \mathrm{~cm})$ were taken at each position with a core-sampler $\left(0.0015 \mathrm{~m}^{2}\right)$, and subsequently frozen for later analysis of $O M, N$, and $P$.

Chemical analysis. Plant samples were analysed for $O M, N$ and $P$ content by standard methods. OM was determined from the weight loss after ignition of dried sub-samples at $465^{\circ} \mathrm{C}$ for $3 \mathrm{~h}$ and the $\mathrm{C}$ and $\mathrm{N}$ concentrations were measured with a Carlo-Erba CHN elemental analyser. The $\mathrm{P}$ content was determined by means of a modified Kjeldahl procedure, using standard colorimetric methods (Grasshoff et al. 1983) after reduction with $\mathrm{H}_{2} \mathrm{SO}_{4}$. Plant-bound $\mathrm{OM}, \mathrm{N}$, and $\mathrm{P}$ per $\mathrm{m}^{2}$ were estimated by multiplying the concentrations of $O M, N$, and $P$ in living and dead plant material with the biomass of living and dead plant material, respectively.

Sediment samples (without visible plant parts) were homogenized, and sub-samples were subsequently analysed for $\mathrm{CaCO}_{3}, \mathrm{OM}, \mathrm{N}$, and $\mathrm{P}$ by standard methods. Microscopic OM was measured as the weight loss after ignition of dry sediment sub-samples at $465^{\circ} \mathrm{C}$ for at least $3 \mathrm{~h}$. The $\mathrm{CaCO}_{3}$ content was subsequently determined on the same sub-samples as the additional weight loss after ignition at $765^{\circ} \mathrm{C}$ for $3 \mathrm{~h}$. The sediment pools of $\mathrm{N}$ and $\mathrm{P}$ were divided into readily available and residual $N$ and $P$, respectively. Available $N$ was measured as $\mathrm{KCl}$-exchangeable ammonium and 
available $\mathrm{P}$ was measured as the ortho-P concentration in small isolated porewater samples (Grasshoff et al. 1983). Residual $N$ and $P$ were analysed using the modified Kjeldahl procedure (as for plant material above) giving total $N$ and $P$ in the sample. Values for available $\mathrm{N}$ and $\mathrm{P}$ were subtracted from total $\mathrm{N}$ and $\mathrm{P}$ content to obtain residual $N$ and $P$. All sediment variables are reported in units of $\mathrm{g} \mathrm{m}^{-2}$ in the upper $10 \mathrm{~cm}$ layer of the sediment.

Statistical treatment. The stocks of OM, N, P, and $\mathrm{CaCO}_{3}$ were compared between locations situated outside, at the edge, and inside the seagrass patches using 1-way ANOVA. Plants were only present at the edge and inside the patches, so plant-bound stocks were compared using Student's t-test. Data were logtransformed when necessary to obtain normality and homogeneity among variances. Associations between stocks of OM, N, and $P$, and seagrass biomass were analysed using Pearson's Product Moment Correlation, and rates of accumulation/depletion of OM, N, P, and plant biomass were computed using Least Square Linear Regression with time since colonization as the independent variable. Data were log-transformed when necessary to obtain normality of data and linearity between variables.

\section{RESULTS}

\section{Plant biomass, time since colonization and plant nutrients}

The time elapsed since colonization by Cymodocea nodosa ranged from 7 to $69 \mathrm{PI}$, corresponding to 0.5 to 4.9 yr (Table 1). Living $C$. nodosa biomass ranged from 30 to $864 \mathrm{~g} \mathrm{DW} \mathrm{m}^{-2}$ (avg $332 \mathrm{~g} \mathrm{DW} \mathrm{m}^{-2}$; Table 1), and biomass increased linearly with time since colonization $\left(\log y=0.98 \log x+0.91, R^{2}=35.3 \%, p<0.001\right)$. Average tissue concentrations of $\mathrm{N}$ were 2.14 and $0.99 \%$ of DW in leaves and roots-rhizomes, respectively, while tissue concentrations of $\mathrm{P}$ were 0.09 and $0.05 \%$ of DW in the same plant fractions (Table 1). Tissue concentra-

Table 1. Summary statistics for Cymodocea nodosa biomass (g DW $\mathrm{m}^{-2}$ ), time since colonization (PI), and tissue concentrations of $\mathrm{N}$ and $\mathrm{P}(\%$ of $\mathrm{DW})$ in leaves and root-rhizomes

\begin{tabular}{|lccc|}
\hline Variable & Average & SD & Range \\
& & & \\
Biomass & 332.4 & 245.5 & $29.9-863.9$ \\
Time since colonization & 35.2 & 16.8 & $7.0-69.0$ \\
Tissue N, leaves & 2.136 & 0.083 & $1.675-2.597$ \\
Tissue N, root-rhizomes & 0.994 & 0.055 & $0.568-1.365$ \\
Tissue P, leaves & 0.091 & 0.006 & $0.067-0.145$ \\
Tissue P, root-rhizomes & 0.047 & 0.004 & $0.023-0.086$ \\
\hline
\end{tabular}

tions of $\mathrm{N}$ and $\mathrm{P}$ were independent of both biomass and time since colonization $(\mathrm{p}>0.05$, Pearson's Product Moment Correlation).

\section{Pool sizes in bare and vegetated areas}

The pool of total OM (i.e. microscopic OM + plantbound $O M$ ) increased from $859 \mathrm{~g} \mathrm{~m}^{-2}$ outside the patches to 1059 and $1336 \mathrm{~g} \mathrm{~m}^{-2}$ at the edge and centre positions ( $\mathrm{p}<0.001$; Table 2, Fig. 2A). This increase was caused solely by the presence of dead and living plant material, accounting for 11 and $26 \%$ of all the OM present at the edge and centre positions. The fraction of microscopic OM increased slightly, but non-significantly ( $p=0.164$ ) from $859 \mathrm{~g} \mathrm{~m}^{-2}$ on bare sand to $989 \mathrm{~g} \mathrm{~m}^{-2}$ in the centre of patches.

The total $\mathrm{N}$ pool increased from $14 \mathrm{~g} \mathrm{~m}^{-2}$ in bare areas to 19 and $28 \mathrm{~g} \mathrm{~m}^{-2}$ at the edge and centre positions, respectively ( $\mathrm{p}<0.001$; Table 2, Fig. $2 \mathrm{~B}$ ). Available $\mathrm{N}$ comprised only 1 or $2 \%$ of the total $\mathrm{N}$ pool, and was only slightly higher in vegetated compared to bare areas ( $p=0.068$ ). Plant-bound $N$ (dead plus alive) increased from 12 to $29 \%$ of the total $N$ pool from the edge to the centre of patches ( $p<0.01$; Table 2). The residual $\mathrm{N}$ fraction, containing a mixture of mineraland organically bound $\mathrm{N}$, increased from $14 \mathrm{~g} \mathrm{~m}^{-2}$ in bare areas to 16 and $19 \mathrm{~g} \mathrm{~m}^{-2}$ at the edge and centre positions, respectively ( $p<0.01$; Table 2 ), and made up the largest $\mathrm{N}$ component as it comprised 98, 86 and $69 \%$ of the total $N$ pool at the 3 positions.

The pools of total $\mathrm{P}$ were large $\left(34\right.$ to $36 \mathrm{~g} \mathrm{~m}^{-2}$; Fig. 2C) and did not differ between bare and vegetated areas ( $p>0.05$; Table 2). Residual $P$ comprised by far

Table 2. ANOVA and $t$ statistics for comparisons of the various pools of organic matter (OM), N, P, and $\mathrm{CaCO}_{3}$ at locations situated outside $(O)$, at the edge $(E)$, and within the centres (C) of Cymodocea nodosa patches in Alfacs Bay. Student's ttest was applied when only 2 locations were compared (i.e. all variables including plant-bound $O M, N$, and $P$ )

\begin{tabular}{|c|c|c|c|}
\hline Variable & $\begin{array}{l}\text { For } t \\
\text { value }\end{array}$ & $\mathrm{p}$ & $\begin{array}{c}\text { Tukey } \\
\text { test }\end{array}$ \\
\hline Plant-bound OM & $t=2.20$ & 0.040 & $E<C$ \\
\hline Residual OM & $F=1.92$ & 0.164 & $O=E=C$ \\
\hline Total OM & $F=9.13$ & 0.001 & $\mathrm{O}<\mathrm{C}$ \\
\hline Plant-bound $N$ & $\mathrm{t}=2.92$ & 0.009 & $\mathrm{E}<\mathrm{C}$ \\
\hline Available N & $F=2.94$ & 0.068 & $O=E=C$ \\
\hline Residual N & $F=7.50$ & 0.002 & $\mathrm{O}<\mathrm{C}$ \\
\hline Total N & $F=14.77$ & 0.000 & $O<E<C$ \\
\hline Plant-bound P & $t=2.63$ & 0.016 & $O=E<C$ \\
\hline Available P & $F=0.43$ & 0.654 & $O=E=C$ \\
\hline Residual P & $F=1.36$ & 0.272 & $O=E=C$ \\
\hline Total P & $F=0.81$ & 0.453 & $O=E=C$ \\
\hline $\mathrm{CaCO}_{3}$ & $F=3.99$ & 0.032 & $\mathrm{O}>\mathrm{C}$ \\
\hline
\end{tabular}



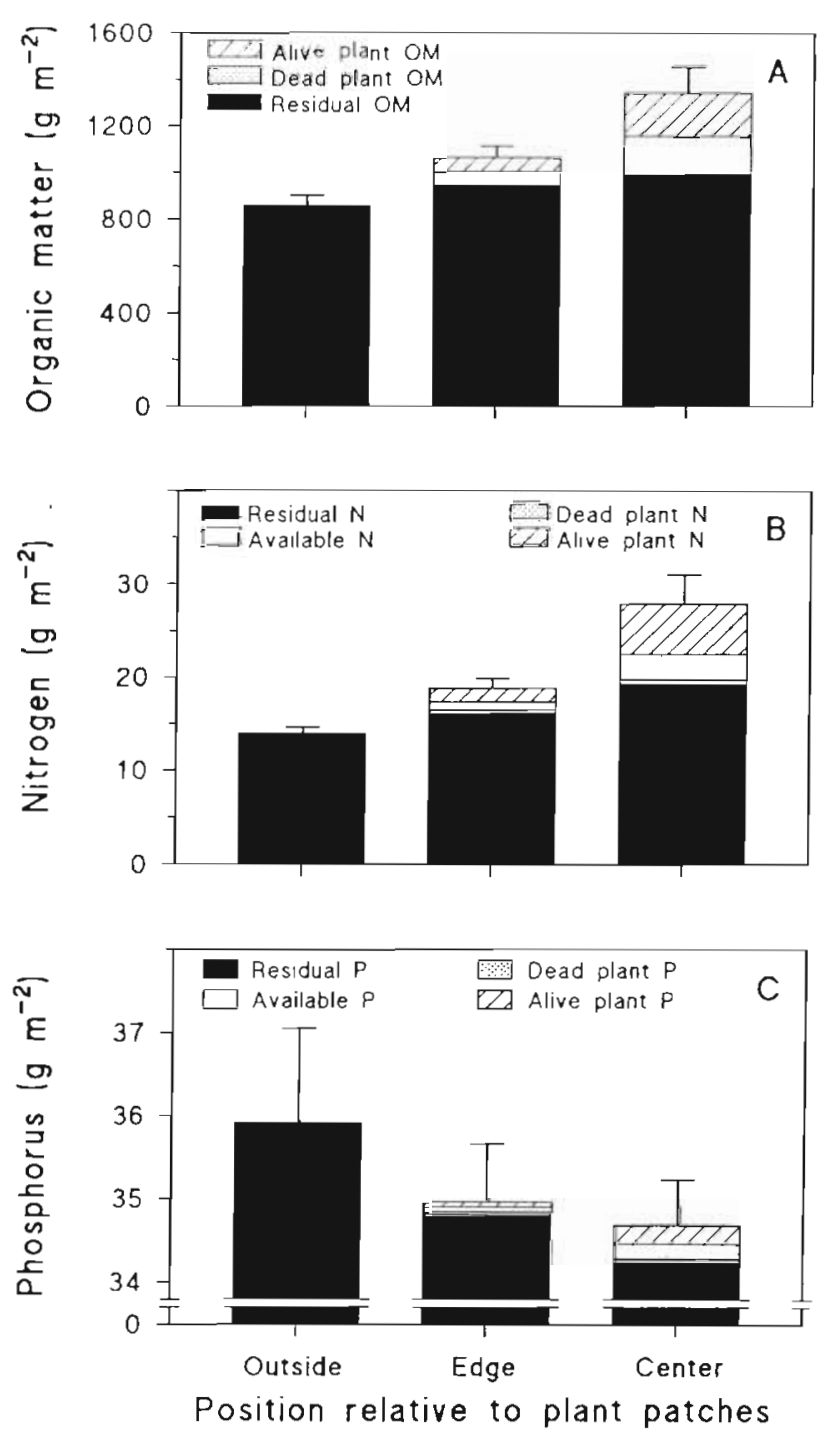

Fig. 2. Average stocks of (A) organic matter (OM), (B) nitrogen $(N)$ and $(C)$ phosphorus $(P)$ in non-vegetated sediments (outside) and within (edge and centre) patches of Cymodocea nodosa in Alfacs Bay. Stacked bars represent the total stocks of $O M, N$, and $P$

the largest $\mathrm{P}$ fraction $(99.9,99.6$ and $98.7 \%)$ at all 3 positions, and tended to decrease, albeit non-significantly ( $p=0.272$; Table 2 ), from non-vegetated areas towards the central position of the patches. Available P ranged from 0.03 to $0.04 \mathrm{~g} \mathrm{~m}^{-2}$, and showed no significant change with location. Plant-bound $\mathrm{P}$ increased 3 -fold from $0.12 \mathrm{~g} \mathrm{~m}^{-2}$ at edge positions to $0.40 \mathrm{~g} \mathrm{~m}^{-2}$ in the centre $(p=0.016$; Table 2$)$, but represented only 0.3 and $1.2 \%$ of the total P stocks at these locations

The $\mathrm{CaCO}_{3}$ content averaged $34.2( \pm 1.6) \%$ of DW in bare sediments, but decreased significantly $(p<0.05$, 1 -way ANOVA; Table 2$)$ to $31.7( \pm 2.1) \%$ of DW at the edge and $27.7( \pm 1.3) \%$ of DW at the central positions of plant patches

\section{Pool changes during seagrass development}

Increasing biomass of Cymodocea nodosa was associated with increasing stocks of $O M$ and $N$. Microscopic $O M$, plant-bound $O M$, and total $O M$ were all positively correlated to seagrass biomass, and so were all fractions of $\mathrm{N}$ (Table 3). The development of biomass was also associated with a significant net increase in available and plant-bound $P$, while the pool of residual $P$ was inversely and significantly correlated to biomass (Table 3 ). The opposite trends in available $\mathrm{P}$, plant-bound $\mathrm{P}$ and residual $\mathrm{P}$ with increasing biomass resulted in a negative, but nonsignificant correlation between total $\mathrm{P}$ and biomass $(p=0.247$; Table 3$)$.

The relations between stocks of $O M, N, P$, and seagrass biomass and time since colonization allowed the net rate of change to be estimated. Total OM accumulated at a rate of $96.9( \pm 37.9) \mathrm{g} \mathrm{m}^{-2} \mathrm{yr}^{-1}$ (Table 4 , Fig $3 \mathrm{~A}$ ). This build up was solely caused by the accumulation of plant biomass $\left(115.9 \pm 25.1 \mathrm{~g} \mathrm{~m}^{-2} \mathrm{yr}^{-1}\right)$, whereas the amount of microscopic OM was unrelated to time since colonization. All $\mathrm{N}$ pools except that of available $\mathrm{N}$ increased significantly with time since colonization (Table 4, Fig. 3B). Total $\mathrm{N}$ accumulated with a rate of $3.57( \pm 0.99) \mathrm{g} \mathrm{m}^{-2} \mathrm{yr}^{-1}$, with most of this accumulation being caused by the build up of residual and plant-bound $N$ (1.40 and $1.81 \mathrm{~g} \mathrm{~m}^{-2} \mathrm{yr}^{-1}$, respectively). Plant-bound $\mathrm{P}$ accumulated at a rate of $0.10 \pm 0.03 \mathrm{~g}$ $\mathrm{m}^{-2} \mathrm{yr}^{-1}$, but was the only $\mathrm{P}$ pool that changed significantly with the time since colonization (Table 4, Fig. 3C). The pool of total $\mathrm{P}$ remained stable with time since colonization with a weak trend to decrease over time, and, thus, the accumulation of plant-bound $\mathrm{P}$ was partially offset by the tendency for the residual $\mathrm{P}$ pool to decrease $\left(-0.24 \pm 0.31 \mathrm{~g} \mathrm{~m}^{-2} \mathrm{yr}^{-1}\right)$.

Table 3. Pearson's Product Moment correlation between Cymodoced nodosa blomass and various fractions of organic matter (OM.) and major nutrents ( $\mathrm{N}$ and $\mathrm{P}$ ). Correlation coefficients ( $r$ ), coefficients of determination $\left(R^{2}\right)$, and levels of significance $(p)$ are given

\begin{tabular}{|lrrr|}
\hline Variable & $\mathrm{r}$ & $\mathrm{R}^{2}$ & \multicolumn{1}{c|}{$\mathrm{p}$} \\
& & & \\
Residual OM & 0.32 & 0.10 & 0.024 \\
Plant-bound OM & 0.92 & 0.85 & $<0.001$ \\
Total OM & 0.84 & 0.71 & $<0.001$ \\
Residual N & 0.82 & 0.67 & $<0.001$ \\
Available N & 0.65 & 0.42 & $<0.001$ \\
Plant-bound N & 0.95 & 0.90 & $<0.001$ \\
Total N & 0.93 & 0.86 & $<0.001$ \\
Residual P & -0.28 & 0.08 & 0.049 \\
Available P & 0.47 & 0.22 & 0.001 \\
Plant-bound P & 0.92 & 0.85 & $<0.001$ \\
Total P & -0.17 & 0.03 & 0.247 \\
\hline
\end{tabular}




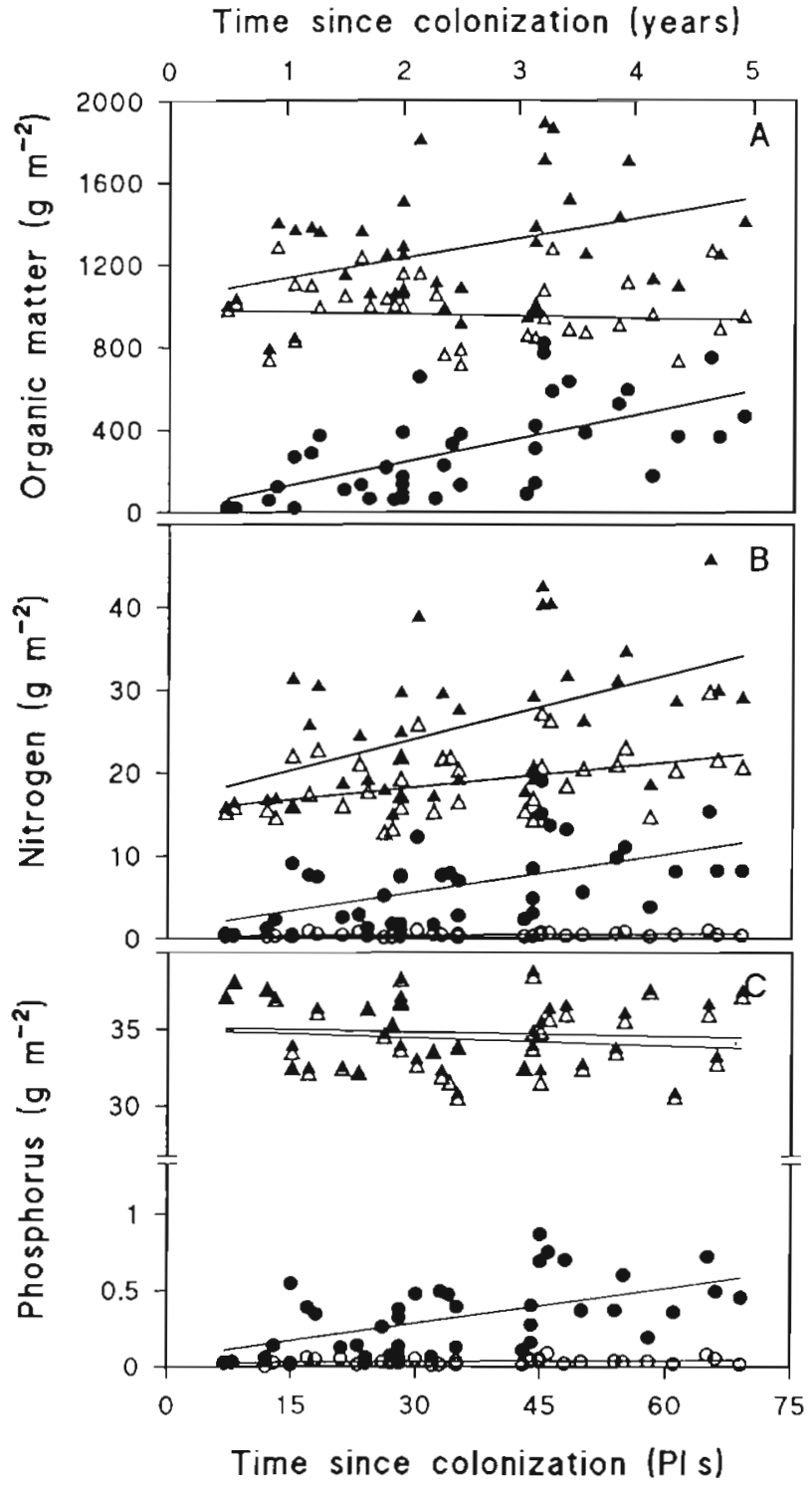

Fig. 3. Changes in stocks of organic matter $(\mathrm{OM})$, nitrogen $(\mathrm{N})$, and phosphorus (P) with time since colonization by Cymodocea nodosa in Alfacs Bay. (A) Changes in plant-

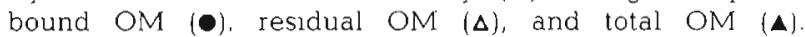
(B) Changes in available $\mathrm{N}(\mathrm{O})$, plant-bound $\mathrm{N}(\mathbf{})$, residual $\mathrm{N}$ $(\Delta)$, and total $N(\Delta)$. (C) Changes in available $P(O)$, plantbound $P(\bullet)$, residual $P(\Delta)$, and total $P(\Delta)$

\section{DISCUSSION}

Colonization and development of Cymodocea nodosa stands in Alfacs Bay were followed by an accumulation of total $\mathrm{N}$, whereas the stocks of total $\mathrm{P}$ remained almost unaffected. More interesting, however, was the redistribution among the various $\mathrm{N}$ and $\mathrm{P}$ fractions along with the development of biomass which provide the possibility to speculate on the nutrient sources for C. nodosa, and also, to address the question on whether seagrass patches act as a sink or a source of $N$ and $P$ in Alfacs Bay.

The non-vegetated sediments of Alfacs Bay were rich in $\mathrm{N}$ and $\mathrm{P}$, but most of these nutrients were probably not readily available for plants as they were, by and large, present in the residual fractions (98 and $99.9 \%$, respectively). We made no attempt to fractionate the residual pools further, but the ratios of organic carbon in the sediment to residual $\mathrm{N}$ and $\mathrm{P}$ may provide insight into whether the nutrients were attached to and included in mineral or organic fractions. The bare sediments contained $859 \mathrm{~g} \mathrm{OM} \mathrm{m}^{-2}$ corresponding to ca $221 \mathrm{~g}$ organic $\mathrm{C} \mathrm{m}^{-2}$ (Vidal et al. 1992), giving estimated $\mathrm{C}: \mathrm{N}$ and $\mathrm{C}: \mathrm{P}$ ratios of 19 and 16 , respectively. The $\mathrm{C}: \mathrm{N}$ ratio is comparable to those normally found in sedimentary OM (e.g. Boynton \& Kemp 1985, Kristensen et al. 1995, Isaksen \& Finster 1996), suggesting that most residual $N$ within the sediments is contained in OM. Most of the residual $N$ is thus available to the plants through remineralization. In contrast, the observed C:P ratio of 16 is much lower than expected for OM in marine sediments (e.g. Boynton \& Kemp 1985), suggesting that much of the residual $P$ is attached to minerals, probably adsorbed to $\mathrm{CaCO}_{3}$, which was present in high concentrations within the sediments (averaging $0.34 \mathrm{~g} \mathrm{CaCO}_{3} \mathrm{~g}^{-1} \mathrm{DW}$ ).

The biomass of Cymodocea nodosa per unit area increased over the first 5 yr after colonization, so the nutrient limitation these plants experience (Perez et al. 1991) did not prevent biomass development. Suspected $P$ limitation of the $C$. nodosa populations in Alfacs Bay was supported by the low tissue concentrations of $\mathrm{P}$ that we observed $(0.07$ to $0.15 \%$ of DW). Plant-bound $\mathrm{N}$ and $\mathrm{P}$ accumulated above the levels made possible by simply exploiting the readily available nutrient pools present prior to colonization, and, thus, nutrients must either have been imported from the water column or, alternatively, have been mobilized from the residual nutrient pools within the sediment.

We estimated a net accumulation of $3.6 \mathrm{~g}$ total $\mathrm{N} \mathrm{m}^{-2}$ $\mathrm{yr}^{-1}$, and the development of plant-bound $\mathrm{N}$ can, therefore, not be explained by redistribution of $\mathrm{N}$ among the various $\mathrm{N}$ pools alone. Thus, the presence of Cymodocea nodosa must have facilitated the import of $\mathrm{N}$ from the water, either by increasing rates of $\mathrm{N}_{2}$ fixation and sedimentation and/or by increasing the amount of inorganic $\mathrm{N}$ taken up from the water by leaves. $\mathrm{N}_{2}$ fixation is often enhanced within seagrass stands (e.g. Capone 1988), but rates are generally low and seem insignificant in comparison with $\mathrm{N}$ input rates from sedimentation and leaf uptake (Hemminga et al. 1991). Macrophyte canopies reduce water flow and turbulence (Fonseca et al. 1982, 1983, Worcester 1995), which may increase sedimentation of particulate mat- 
Table 4. Linear regression equations describing the relationships between different fractions of organic matter $(O M)$, nitrogen $(N)$ and phosphorus $(P)$ and the tume elapsed since colonization by Cymodocea nodosa. All pool sizes are given in units of $\mathrm{g} \mathrm{m}^{-2}$, while the time since colonization is given in years

\begin{tabular}{|lcccr|}
\hline Variable & $\begin{array}{c}\text { Slope } \\
\left(\mathrm{g} \mathrm{m}^{-2} \mathrm{yr}^{-1}\right)\end{array}$ & $\begin{array}{c}\text { Intercept } \\
\left(\mathrm{g} \mathrm{m}^{-2}\right)\end{array}$ & $\mathrm{R}^{2}$ & $\mathrm{p}$ \\
\cline { 1 - 4 } Residual OM & $-19.0( \pm 20.5)$ & $1030.5( \pm 57.1)$ & 0.023 & 0.359 \\
Plant-bound OM & $115.9( \pm 25.1)$ & $9.6( \pm 69.8)$ & 0.366 & $<0.001$ \\
Total OM & $96.9( \pm 37.9)$ & $1038.8( \pm 105.8)$ & 0.154 & 0.015 \\
Residual N & $1.40( \pm 0.50)$ & $15.28( \pm 1.39)$ & 0.17 & 0.008 \\
Available N & $0.04( \pm 0.03)$ & $0.33( \pm 0.08)$ & 0.06 & 0.147 \\
Plant-bound N & $1.81( \pm 0.64)$ & $2.12( \pm 1.90)$ & 0.19 & 0.009 \\
Total N & $3.57( \pm 0.99)$ & $16.54( \pm 2.79)$ & 0.26 & 0.001 \\
Residual P & $-0.238( \pm 0.311)$ & $34.92( \pm 0.86)$ & 0.02 & 0.448 \\
Available P & $0.004( \pm 0.003)$ & $0.02( \pm 0.01)$ & 0.08 & 0.093 \\
Plant-bound P & $0.099( \pm 0.030)$ & $0.08( \pm 0.08)$ & 0.26 & 0.001 \\
Total P & $-0.132( \pm 0.305)$ & $35.09( \pm 0.85)$ & 0.01 & 0.667 \\
\hline
\end{tabular}

ter within the stands. Although the observed accumulation of $\mathrm{N}$ could indicate enhanced sedimentation of $\mathrm{N}$-rich material, we found no parallel increase in microscopic OM or $\mathrm{P}$, suggesting that the significance of enhanced sedimentation was small. The concentration of inorganic $N$ in Alfacs Bay is rather high, ranging from 3 to $100 \mu \mathrm{M}$ in the water column and from 200 to $400 \mu \mathrm{M}$ in the porewater [Table 1 in Perez et al. (1994)]. Assuming that the $\mathrm{N}$ uptake kinetics of $C$. nodosa resemble those of other seagrasses (e.g. Ruppia maritima; Thursby \& Harlin 1984), then leaf uptake should be able to supply from 13 to $53 \%$ of the total $\mathrm{N}$ taken up by the plants, thereby providing a substantial input of $\mathrm{N}$ from the water to the plant patches which can partly explain the observed net accumulation of total $\mathrm{N}$.

The pool of total $\mathrm{P}$ remained constant, or decreased slightly, with increasing biomass and time elapsed since colonization, and the possibility exist, therefore, that the observed accumulation of plant-bound P was caused by redistribution of $P$ among pools already present in the system prior to colonization, e.g. from the residual $\mathrm{P}$ pool. If the development of Cymodocea nodosa biomass is based upon $\mathrm{P}$ made available through mineralization of organic $\mathrm{P}$ and/or dissolution of Ca-bound $P$, then most $P$ has to be obtained through the roots. Concentrations of inorganic $P$ in the water and porewater in Alfacs Bay range from 0.08 to $2 \mu \mathrm{M}$ and from 4 to $30 \mu \mathrm{M}$, respectively [Table 1 in Perez et al. (1994)]. Using these concentrations with Carignan's (1981) empirical model for P uptake by aquatic macrophytes, root uptake is estimated to account for 78 to $90 \%$ of the total P taken up by $C$. nodosa.

Although carbonate-rich sediments contain large stocks of $\mathrm{P}$ bound in calcium-fluoro-apatite and other Ca compounds (Jensen et al. 1997), growth of sea- grasses is often $P$ limited in such areas (e.g. Short et al. 1985, 1990, Perez et al. 1991) and Ca-bound $\mathrm{P}$ is, therefore, often assumed to be hardly available or unavailable to the plants (Patriquin 1972, Erftemeijer \& Middelburg 1993). Slow mobilization and subsequent use of Ca-bound $\mathrm{P}$ has been reported for terrestrial plants, however (see reviews by Gorham et al. 1979, Lambers \& Poorter 1992), and studies by Morse et al. (1987) and Jensen et al. (1997) indicate that seagrasses can draw P from pools of carbonate-bound $P$. Carbonate dissolution and mobilization of adsorbed $P$ may be related to plant metabolism through the breakdown of organic matter followed by a decrease of $\mathrm{pH}$ around the rhizosphere and/or by the direct action of organic acids released from plant roots (Gorham et al. 1979, Hoffland et al. 1989, Kpomblekou \& Tabatabai 1994). The negative correlation between biomass and residual $P$ (or time elapsed since colonization) and the decrease in $\mathrm{CaCO}_{3}$ content under plant cover suggest, therefore, that carbonate-bound $\mathrm{P}$ is slowly exploited to support continued development of seagrass biomass in the study area. The slow depletion of the residual $\mathrm{P}$ pool $\left(0.2 \mathrm{~g} \mathrm{P} \mathrm{m}^{-2} \mathrm{yr}^{-1}\right)$ seems sufficient to cover the observed accumulation of plant-bound $\mathrm{P}\left(0.1 \mathrm{~g} \mathrm{P} \mathrm{m}^{-2} \mathrm{yr}^{-1}\right)$. Our data on total and residual $\mathrm{P}$ pools suffer from large scatter due to high spatial heterogenity within the system which leaves correlations between pool size and time non-significant. Detailed studies on the development of the residual $P$ pools and their interaction with carbonates in the sediments are, therefore, needed in the future to evaluate this matter better In summary, our data suggest that the rate of biomass increase is governed by the capability of Cymodocea nodosa to sequester the limiting $P$ from the pool of residual $P$ within the sediments. The striking contrast between the increase in total $N$ stocks with time since colonization and the opposite trend in residual stocks of $P$ reflects, therefore, that the development of plant cover may affect the pools of different nutrient elements in different manners.

Cymodocea nodosa covers 10 to $20 \%$ in Alfacs Bay (Perez \& Camp 1986), and we suggest that its presence plays an important role in the retention of $N$ within the Bay, because it favors a net accumulation of $\mathrm{N}$ above that in nearby non-vegetated areas. In contrast, $C$. nodosa play no role in the retention of $P$, and it may actually act as a source of $\mathrm{P}$ due to exploitation and subsequent release of otherwise unavailable $P$ in the sediment. Our results support the conventional wis- 
dom that development of seagrass meadows is accompanied by substantial changes in both the size and the partitioning of the different nutrient pools present, but, further, we provide estimates of the rates involved. The effect of the plants depends on the form and availability of nutrients in the system, and we suggest that colonization and development of seagrass populations may cause excess nutrients to become trapped and accumulated, while limiting nutrients may be mobilized and maybe released from the system.

Acknowledgements. We thank Birgit Kjoller for valuable support with all the nutrient analysis. M.F.P. was supported by the Danish SMP-program (\#4.20).

\section{LITERATURE CITED}

Boynton WR, Kemp WM (1985) Nutrient regeneration and oxygen consumption by sediments along an estuarine salinity gradient. Mar Ecol Prog Ser 23:45-55

Capone DG (1988) Benthic nitrogen fixation. In: Blackburn TH, Sørensen J (eds) Nitrogen cycling in coastal marine environments. Scope 33. Wiley \& Sons, Chichester, p $85-114$

Carignan R (1981) An empirical model to estimate the relative importance of roots in phosphorus uptake by aquatic macrophytes. Can J Fish Aquat Sci 39:243-247

Costanza R, d'Arge R, de Groot R, Farber S, Grasso M, Hannon B, Limburg K, Naeem S, O'Neill RV, Paruelo J, Raskin RG, Sutton $P$, van der Belt $M$ (1997) The value of the world's ecosystem services and natural capital. Nature $387: 253-260$

Crew TE, Kitayama K, Fownes JH, Riley RH, Herbert DA, Mueller-Dombois D, Vitousek PM (1995) Changes in soil phosphorus fractions and ecosystem dynamics across a long chronosequence in Hawaii. Ecology 76:1407-1424

Duarte CM, Marbá N, Agawin N, Cebrián J, Enríguez $S$, Fortes MD, Gallegos ME, Merino M. Olesen B, SandJensen K, Uri J, Vermaat J (1994) Reconstruction of seagrass dynamics: age determinations and associated tools for the seagrass ecologist. Mar Ecol Prog Ser 107:195-209

Erftemeijer PLA, Middelburg JJ (1993) Sediment-nutrient interactions in tropical seagrass beds: a comparison between a terrigenous and a carbonate sedimentary environment in South Sulawesı (Indonesia). Mar Ecol Prog Ser 102:187-198

Fonseca MS, Fisher JS, Zieman JC, Thayer GW (1982) Influence of the seagrass, Zostera marina L., on current flow. Estuar Coast Shelf Sci 15:351-364

Fonseca MS, Zieman JC, Thayer GW, Fisher JS (1983) The role of current velocity in structuring eelgrass (Zostera marina L.) meadows. Estuar Coast Shelf Sci 17:367-380

Gorham E, Vitousek PM, Reiners WA (1979) The regulation of chemical budgets over the course of terrestrial ecosystem succession. Annu Rev Ecol Syst 10:53-84

Grasshoff K, Ehrhardt M, Kremling K (1983) Methods of seawater analysis. Verlag Chemie, Weinheim

Hemminga MA, Harrison PG, van Lent F (1991) The balance of nutrient losses and gains in seagrass meadows. Mar Ecol Prog Ser 71:85-96

Hoffland E, Findenegg GR, Nelemans JA (1989) Solubilization of rock phosphate by rape II. Local root exudation of organic acids as a response to P-starvation. Plant Soil 113:161-165
Isaksen MF, Finster K (1996) Sulphate reduction in the root zone of the seagrass Zostera noltii on the intertidal flats of a coastal lagoon (Arcachon, France). Mar Ecol Prog Ser 137:187-194

Jensen HS, McGlathery KJ, Marino R, Howarth RW (1997) Forms and availability of sediment phosphorus and carbonate sand of Bermuda seagrass beds. Limnol Oceanogr (in press)

Kenworthy WJ, Zieman JC. Thayer GW (1982) Evidence for the influence of seagrasses on the benthic nitrogen cycle in a coastal plain estuary near Beaufort, North Carolina (USA). Oecologia 54:152-158

Kpomblekou AK, Tabatabai MA (1994) Effect of organic acids on release of phosphorus from phosphate rocks. Soil Sci 158:442-453

Kristensen E, Holmer M, Banta G, Jensen M, Hansen K (1995) Carbon, nitrogen and sulphur cycling in sediments of the Ao Nam Bor mangrove forest, Phuket. Thailand: a review. Phuket Mar Biol Cent Res Bull 60:37-64

Lambers $H$, Poorter $H$ (1992) Inherent variation in growth rate between higher plants: a search for physiological causes and ecological consequences. Adv Ecol Res 23:188-222

Marbá N, Duarte CM (1995) Coupling of seagrass (Cymodocea nodosa) patch dynamics to subaqueous dune migration. J Ecol 83:381-389

Morse JW, Zullig JJ, Iverson RL, Chopping GR, Mucci A, Millero FJ (1987) The influence of seagrass beds on carbonate sediments in the Bahamas. Mar Chem 22:71-83

Patriquin DG (1972) The origin of nitrogen and phosphorus for growth of the marine angiosperm Thalassia testudinum. Mar Biol 15:35-46

Perez M, Camp J (1986) Distribución espacialy biomasa de las fanerógamas marinas de las Bahias del Delta del Ebro. Invest Pesq 50:519-530

Perez M. Duarte CM, Romero J, Sand-Jenser. K, Alcoverro T (1994) Growth plasticity in Cymodocea nodosa stands: the importance of nutrient supply. Aquat Bot 47:249-264

Perez M, Romero J, Duarte CM, Sand-Jensen K (1991) Phosphorus limitation of Cymodocea nodosa grawth. Mar Biol 109:129-133

Romero J, Pergent G, Pergent-Martini C, Mateo M, Regnier C (1992) The detritic compartment in a Posidonia oceanica meadow: litter features, decomposition rates, and mineral stocks. PSZN I: Mar Ecol 13:69-83

Short FT (1987) Effects of sediment nutrients on seagrasses: literature review and mesocosm experiment. Aquat Bot $27: 41-57$

Short FT, Davis MW, Gibson RA, Zimmermann CF (1985) Evidence for phosphorus limitation in carbonate sediments of the seagrass Syringodium filiforme. Estuar Coast Shelf Sci $20: 419-430$

Short FT, Dennison WC, Capone DG (1990) Phosphorus limited growth of the tropical seagrass Syringodium filiforme in carbonate sediments. Mar Ecol Prog Ser 62:169-174

Thursby GB, Harlin MM (1984) Interaction of leaves and roots of Ruppia maritima in the uptake of phosphate, ammonia and nitrate. Mar Biol 83:61-67

Tiessen $H_{1}$ Stewart JWB (1985) The biogeochemistry of soil phosphorus. In: Caldwell J, Brierly A, Brierly CL (eds) Planetary ecology. Van Nostrand Reinhold, New York, p $463-472$

Tilman D (1985) The resource ratio hypothesis of succession. Am Nat 125:827-852

Tilman D (1988) Plant strategies and the dynamics and structure of plant communities. Princeton University Press Princeton, NJ

Vidal M, Morgui JA, Latasa M, Romero J, Camp J (1992) Fac- 
tors controlling spatial variability in ammonium release within an estuarine bay (Alfacs Bay, Ebro Delta, NW Mediterranean). Hydrobiologia 235/236:519-525

Vitousek PM, Reiners WA (1975) Ecosystem succession and nutrient retention: a hypothesis. BioScience 25:376-381

Walker TW, Syers JK (1976) The fate of phosphorus during

Editorial responsibility: Otto Kinne (Editor), Oldendorf/Luhe, Germany pedogenesis. Geoderma 15:1-19

Williams SL (1990) Experimental studies of Caribbean seagrass bed development. Ecol Monogr 60:449-469

Worcester SE (1995) Effects of eelgrass beds on advection and turbulent mixing in low current and low shoot density environments. Mar Ecol Prog Ser 126:223-232

Submitted: January 5, 1997; Accepted: September 24, 1997 Proofs received from author(s): November 10, 1997 